\title{
Hydrological threats to riparian wetlands of international importance - a global quantitative and qualitative analysis
}

\author{
Christof Schneider $^{1}$, Martina Flörke ${ }^{1}$, Lucia De Stefano ${ }^{2}$, and Jacob D. Petersen-Perlman ${ }^{3}$ \\ ${ }^{1}$ Center for Environmental Systems Research, University of Kassel, Kassel, Germany \\ ${ }^{2}$ Department of Geodynamics, Complutense University of Madrid, Madrid, Spain \\ ${ }^{3}$ Department of Geography, Western Oregon University, Monmouth, Oregon, USA \\ Correspondence to: Christof Schneider (schneider@usf.uni-kassel.de)
}

Received: 13 July 2016 - Discussion started: 26 July 2016

Revised: 24 April 2017 - Accepted: 3 May 2017 - Published: 9 June 2017

\begin{abstract}
Riparian wetlands have been disappearing at an accelerating rate. Their ecological integrity as well as their vital ecosystem services for humankind depend on regular patterns of inundation and drying provided by natural flow regimes. However, river hydrology has been altered worldwide. Dams cause less variable flow regimes and water abstractions decrease the amount of flow so that ecologically important flood pulses are often reduced. Given growing population pressure and projected climate change, immediate action is required. However, the implementation of counteractive measures is often a complex task. This study develops a screening tool for assessing hydrological threats to riparian wetlands on global scales. The approach is exemplified on 93 Ramsar sites, many of which are located in transboundary basins. First, the WaterGAP3 hydrological modeling framework is used to quantitatively compare current and future modified flow regimes to reference flow conditions. In our simulations current water resource management seriously impairs riparian wetland inundation at $29 \%$ of the analyzed sites. A further $8 \%$ experience significantly reduced flood pulses. In the future, eastern Europe, western Asia, as well as central South America could be hotspots of further flow modifications due to climate change. Second, a qualitative analysis of the 93 sites determined potential impact on overbank flows resulting from planned or proposed dam construction projects. They take place in one-third of the upstream areas and are likely to impair especially wetlands located in South America, Asia, and the Balkan Peninsula. Third, based on the existing legal/institutional framework and water resource availability upstream, further qualitative analysis evaluated the capacity to preserve overbank
\end{abstract}

flows given future streamflow changes due to dam construction and climate change. Results indicate hotspots of vulnerability exist, especially in northern Africa and the Persian Gulf.

\section{Introduction}

Natural wetland areas have declined at the global scale by $31 \%$ between 1970 and 2008 (Dixon et al., 2016) and even higher numbers are likely for floodplain wetlands specifically. In Europe and North America up to $90 \%$ of all natural floodplains are functionally extinct and in developing countries they are disappearing at an accelerating rate (Tockner and Stanford, 2002). Today, river systems belong to the most threatened ecosystems on the planet, and the global freshwater Living Planet Index, indicating changes in fish, bird, reptile, amphibian, and mammal populations, has declined by $76 \%$ since 1970 (WWF, 2014). One of the main reasons for this situation is the alteration of natural flow regimes due to water resource development (Dynesius and Nilsson, 1994; Kingsford, 2000; Tockner and Stanford, 2002).

Dams are built for different purposes. On the one hand, they offer important benefits and contribute $12-16 \%$ of global food production and $19 \%$ of global electricity generation (WCD, 2000; Richter and Thomas, 2007). On the other hand, dams have been identified as the largest anthropogenic impact on the natural environment (Petts, 1984; Dynesius and Nilsson, 1994; Poff et al., 1997). A study by Nilsson et al. (2005) showed that dams affect $59 \%$ of all large (i.e., natural annual discharge $\geq 350 \mathrm{~m}^{3} \mathrm{~s}^{-1}$ ) river systems glob- 
ally. In the year 2000, the total cumulative storage capacity of large dams accounted for approximately $8300 \mathrm{~km}^{3}$ (Chao et al., 2008; ICOLD, 2007), meaning that more than $20 \%$ of global annual river discharge can be retained in reservoirs (Vörösmarty et al., 1997). In general, dams cause fewer variable flow regimes by considerably dampening flood peaks and elevating low flows. The downstream effects of individual dams reach up to tens or hundreds of kilometers, reducing the extent and frequency of floodplain wetland inundation (Collier et al., 1996; McCully, 1996; Poff et al., 2007). Further decreases in flow are caused by water abstractions of an exponentially growing world population. In the year 2014, $3986 \mathrm{~km}^{3}$ of freshwater were withdrawn globally according to AQUASTAT statistics (FAO, 2016). The main fraction was used by agriculture (69\%), followed by the industrial (19\%) and domestic water supply sectors (12\%).

While floods are known as one of the most damaging natural disasters worldwide, affecting human lives and property (Jonkman, 2005; Doocy et al., 2013; Swiss Re, 2014), they are essential at pristine and not heavily altered floodplains, benefiting river-floodplain ecosystems. A natural river floodplain falls into the wetland category and represents an ecotone at the interface of aquatic and terrestrial realms, which is periodically flooded and dried (Gregory et al., 1991; Bayley, 1995). Here, as described by the flood pulse concept (Junk et al., 1989; Bayley, 1991; Tockner et al., 2000; Junk and Wantzen, 2004), the periodic occurrence of overbank flows is by far the single most important driving force (Welcomme, 1979; Tockner and Stanford, 2002) and engenders one of the most dynamic, diverse, and productive systems in the world (Naiman et al., 1993; Nilsson and Berggren, 2000; Allan et al., 2005). Costanza et al. (1997) estimated the monetary value of ecosystem services from floodplains and swamps at USD 3.2 trillion per year worldwide.

Due to population growth, climate change, and new dam initiatives, impacts on riparian wetlands are very likely to further increase in the next decades. Currently, major initiatives in hydropower development are taking place as a new source of renewable energy. At least 3700 major dams are either planned or under construction, which is supposed to further reduce the number of remaining free-flowing rivers by $21 \%$ (Zarfl et al., 2014). These dams offer economic opportunities, but have the potential to negatively impact river ecosystem health (Lloyd et al., 2004; WWF, 2004; Poff and Zimmermann, 2010) and cause conflicts among upstream and downstream water users. Climate change may severely alter flow regimes over large regional scales as well (Nohara et al., 2006; Laize et al., 2014). Hydrological projections indicate that future flow regimes are likely to be different under climate change due to regionally and seasonally changing precipitation patterns and amounts (Schneider et al., 2013). The higher temperatures will influence timing and quantities of snowmelt (Verzano and Menzel, 2009) as well as frequency and intensity of extreme weather events such as floods (Milly et al., 2008). Okruszko et al. (2011) showed that, depending on the applied scenario, European wetlands could lose 26 to $46 \%$ of their ecosystem services by 2050 due to climatic and socioeconomic impacts on hydrology.

In concept, there are different measures to counteract flow alteration threats to riparian wetlands. However, implementing such measures is a complex task and faces challenges such as setting strategic goals, identifying operation targets, having conflict resolution mechanisms in place, involving stakeholders, and monitoring the entire development (PahlWostl et al., 2013). International reviews (Moore, 2004; Le Quesne et al., 2010) revealed that the main obstacles to environmental flow (eFlow) implementations around the world include insufficient legal and institutional capacities, as well as conflicts of interests regarding available water resources. This is especially the case in transboundary river basins. The more countries affect the water management upstream of a riparian wetland, the more groups of stakeholders with different interests are present. More interdependencies are created at different administrative levels both within and between the countries, and the potential for conflicts is higher (GWP, 2014). Hence, international water treaties and institutions are required to agree on common goals, coordinate basin-wide water management, and allocate water to different users (Le Quesne et al., 2010). In the past, ineffective governance systems have often led to overexploitation of water resources with detrimental effects for river ecosystems and, in the long term, for human well-being (Pahl-Wostl et al., 2013).

Despite the political and legal progress in the last decades (Naiman et al., 2002; Postel and Richter, 2003; Arthington et al., 2006; Poff and Matthews, 2013), most river reaches and wetlands remain vulnerable to overexploitation worldwide (Poff et al., 2009; Richter, 2009; Richter et al., 2012). Regional studies show that floodplain wetlands have been downsized and transformed into terrestrial ecosystems due to reduced flooding caused by water resource management (Hughes, 1988; Maheshwari et al., 1995; Barbier and Thompson, 1998; Kingsford, 2000; Nislow et al., 2002; Middelkoop et al., 2015). Today, the speed of river ecosystem destruction and biodiversity loss is exceeding the ability of scientists to review applied water management practices and ecological consequences for each river. Thus, there is an urgent need to complement more accurate but time-consuming case studies with global water assessments that cover largescale developments (Poff and Matthews, 2013). Accordingly, different authors have assessed ecologically relevant flow regime alterations on larger scales in recent years (e.g., Smakhtin et al., 2004; Smakhtin and Eriyagama, 2008; Döll et al., 2009; Döll and Zhang, 2010; Vörösmarty et al., 2010; Schneider et al., 2013; Laize et al., 2014; Pastor et al., 2014; Grill et al., 2015).

Building on the work from these valuable papers, this study aims at establishing a screening tool to systematically identify riparian wetlands that are threatened due to river flow regime modifications. While most large-scale eFlow assessments focused on in-channel river flows, our assessment 
is the first that applies the flood pulse concept on a global scale. Complex flow-dependent ecosystem habitats such as floodplain wetlands are provided by specific flow events. Consequently, rather than changes in average flow conditions, our modeling approach focuses on overbank flows leading to inundation of adjacent riparian wetlands. Additionally, it considers different drivers of global change such as dam operation, water use, and climate change. As many ecological functions and habitats are facilitated by hydrological events that last only up to a few days (e.g., strong precipitation events, flood formation, and overbank flows), discharge simulations are carried out on a daily time step. The modeling is performed on a detailed river network with a very high spatial resolution for a global model and can be applied for single reaches of larger rivers with a global coverage.

Next to flow regime modifications, the threat to riparian wetlands also depends on the society's capacity to act, which is required to respond to hydrological changes and implement counteractive measures supporting the conservation of riparian wetlands. Capacity to act might be limited due to high water resource competition or deficits in the legal and institutional framework in place, and this kind of threat has not yet been taken into account in large-scale studies. In order to fill this gap, we combined quantitative with qualitative indicators which address upstream water resource availability as well as the presence of institutional arrangements facilitating the establishment of eFlows.

In this study, the proposed screening tool is exemplarily applied to 93 selected riparian wetlands of international importance to address the following research questions.

1. What is the impact of current water resource management on riparian wetland flooding?

2. At which sites is inundation likely to be further modified due to climate change and new dam construction?

3. At which sites could the implementation of conservation measures be hindered by a low capacity to act?

\section{Methodology}

In order to exemplify the proposed screening tool, we selected wetlands based on two criteria. First, we chose wetlands listed under the Ramsar Convention, which is a global framework for intergovernmental cooperation aiming for the conservation and sustainable use of wetlands. This criterion ensured international importance and the significant value of the selected wetlands for humanity as a whole. Second, the wetlands have to be dependent on lateral overspill of adjacent rivers (i.e., fluviogenic). The Ramsar Classification System describes different wetland types, but does not categorize riparian wetlands. However, riparian wetlands were selected from the Ramsar list on the basis of information provided by the Ramsar information sheets (RSIS, 2015), indicating a wetland's dependence on flooding. For Europe, a higher number of sites were chosen as the European wetland geodatabase (Okruszko et al., 2011) clearly defines wetland type and main source of water for each European Ramsar wetland. In total, 93 sites were selected, ranging from 5 to $55374 \mathrm{~km}^{2}$ in size and located in 48 countries and 47 river basins, respectively. The Danube basin had the most selected wetlands of all river basins, with 19 riparian Ramsar wetlands. A detailed list of all wetlands is provided in Sect. S1 in the Supplement.

Our wetland assessment combines a quantitative and a qualitative analysis. The quantitative analysis is based on the flood pulse concept, which describes the flood pulse as a major driver determining the extent of the river floodplain and the biota living within it (Junk et al., 1989; Tockner et al., 2000). For each site we determined the percentage change in flood volume caused by (i) current water resource management and (ii) future climate change. In each case, we compared the modified river flow regimes to reference conditions which reflect near-natural flow regimes.

The qualitative analysis addresses vulnerability due to new dam initiatives as well as a deficient capacity to act. New dam initiatives have the potential to further reduce wetland inundation in the near future. Capacity to act is required to implement complex counteractive measures at threatened sites and equitably allocate water resources to different water use sectors. However, capacity to act is often restricted by deficits in legal and institutional arrangements as well as water resource competition (Moore, 2004; Le Quesne et al., 2010). We address the third research question by identifying riparian wetlands where implementation of conservation measures will likely be hindered by a low capacity to act.

\subsection{The quantitative assessment of threats}

In order to quantitatively assess anthropogenic alterations of flood pulses, we applied WaterGAP3 (Eisner, 2016). WaterGAP3 is an integrated global modeling framework to assess impacts of global change on renewable freshwater resources. The model has been further improved to represent specific flow events (Verzano and Menzel, 2009; Verzano et al., 2012) and identify river ecosystems at risk (Schneider et al., 2013). WaterGAP3 was selected for the study because of the global coverage, the high spatial resolution of 5 by $5 \operatorname{arcmin}(\sim 9 \times 9 \mathrm{~km}$ at the Equator) to represent hydrological processes, the temporal resolution of daily time steps which is important for modeling flood formation, the operation of currently $>6000$ dams with optimization schemes for different dam types, and the calculation of water withdrawals and consumption of five different water-related sectors (domestic, manufacturing industries, thermal electricity production, agricultural crop irrigation, and livestock).

Forced by climatic time series, the hydrology model of WaterGAP3 computes the macro-scale behavior of the terrestrial water cycle. The daily water balances for each grid 


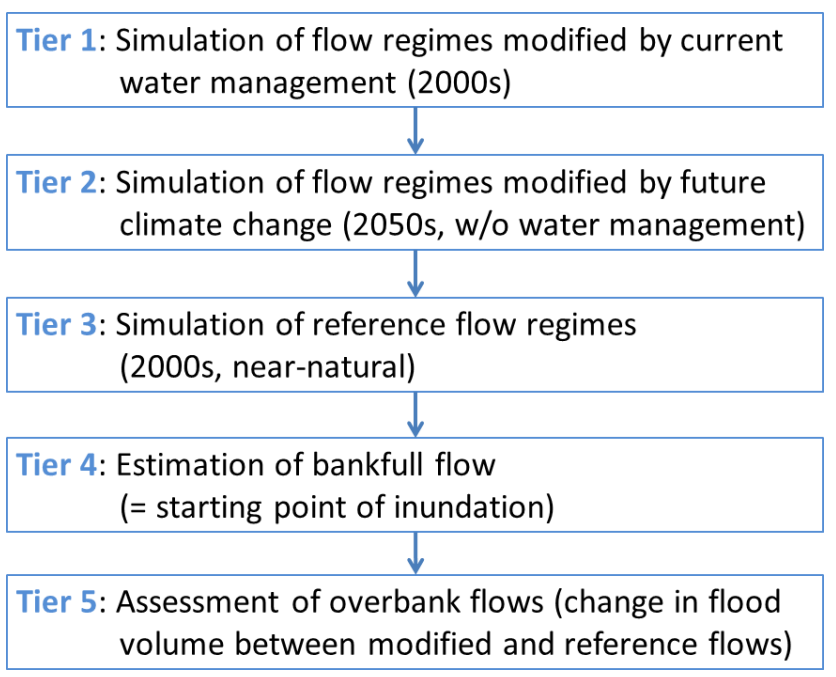

Figure 1. Schematic illustration of the steps taken in the quantitative analysis based on WaterGAP3 modeling.

cell take into account distributed physiographic characteristics from high spatial resolution maps describing slope, soil type, land cover, aquifer type, permafrost, and glaciers, as well as extent and location of lakes and wetlands. The total runoff in each grid cell, derived from the water balances of land and freshwater areas, is routed along a predefined drainage direction map (DDM5; Lehner et al., 2008) to the catchment outlet.

Simulated river flows are calibrated against observed annual discharge data from the Global Runoff Data Centre (GRDC, 2004) at about 1600 gauging stations globally. The calibration process adjusts only one model parameter (i.e., runoff coefficient $\gamma$ ), which has an effect on cell surface runoff generation at gauging stations (Eisner, 2016). In recent studies the model's ability to represent specific flow events has been proven for different maximum flow magnitudes (Schneider et al., 2011a; Schneider, 2015; Eisner, 2016).

In order to assess quantitative changes in floodplain inundation, we conducted different model experiments. Single steps of the entire approach are illustrated in Fig. 1 and described in detail in the following subchapters. In brief, we proceeded as follows: first, we simulated modified river flow regimes under current water resource management (tier 1; Sect. 2.1.1) and climate change (tier 2; Sect. 2.1.2). As assessment of river ecosystem health implies comparison of modified flows to natural flow conditions (Norris and Thoms, 1999), we simulated the reference flow regimes in tier 3 (Sect. 2.1.3) by not accounting for anthropogenic impacts (i.e., dam management and water use) except current climate and land-cover conditions existing in the 2000s. In tier 4 (Sect. 2.1.4), we estimated bankfull flow, which constitutes an important parameter in our analysis. It describes the flow where water just begins to enter the active floodplain and, thus, marks the starting point of inundation. As floodplain in- undation requires overtopping of the banks, each daily flow above bankfull was a critical flow to investigate in tier 5 (Sect. 2.1.5). Here we compared modified (tiers 1 and 2) to reference flow regimes (tier 3 ) and quantified the changes in overbank flows (flood volume) as a proxy for changes in wetland inundation.

\subsubsection{Simulation of modified flow regimes under current water resource management}

For the simulation of flow regimes under current water resource management (i.e., 1981-2010), we took anthropogenic flow alterations due to water use and dam operation into account (tier 1, Fig. 1). Regarding water use, river discharge is reduced in each grid cell by water consumption as calculated by the global water use models of WaterGAP3. These models simulate spatially distributed water uses for the five most important water use sectors (aus der Beek et al., 2010; Flörke et al., 2013).

Net irrigation requirements are simulated for each grid cell based on climatic conditions, dominant crop type, and irrigated area around the year 2005 (GMIAv5; Siebert et al., 2013) assuming an optimal water supply to irrigated crops. Livestock water demands are determined by multiplying the number of animals per grid cell by the livestock-specific water use intensity (Alcamo et al., 2003). For the electricity production sector, the amount of cooling water consumed is calculated by multiplying the water use intensity of each power station by the equivalent annual thermal electricity production. The water use intensity is affected by the cooling system (once-through flow cooling, tower cooling, or ponds) and the type of fuel (coal and petroleum, natural gas and oil, nuclear, or biomass and waste) used at each power station (Flörke et al., 2012). Power station characteristics such as type, size, and location are derived from the World Electric Power Plants Data Set (UDI, 2004).

Consumptive water uses of the manufacturing and domestic sectors are computed on a country scale following data from national statistics and reports, which are subsequently allocated to the grid cells of the associated country by means of urban population and population density maps, respectively (Flörke et al., 2013). For the domestic sector, WaterGAP3 also considers water transfers of 480 larger cities, including their 1642 withdrawal points (City Water Map; McDonald et al., 2014).

In order to assess flow alterations due to dam operation, the number of dams implemented in the model has been further increased based on information provided by the Global Reservoir and Dam (GRanD) database (Lehner et al., 2011). From this dataset, WaterGAP3 now considers all large dams (i.e., dams with a height of $\geq 15 \mathrm{~m}$ ) plus smaller dams exceeding a reservoir storage volume of $0.5 \mathrm{~km}^{2} ; 6025$ dams are currently allocated to the global WaterGAP3 stream net accounting for a total accumulative storage volume of 
$6200 \mathrm{~km}^{3}$. This is state-of-the-art in comparison to other global models (Haddeland et al., 2014).

The operation of dams is performed in WaterGAP3 as a function of dam type. Dams with the main purpose of irrigation are operated according to the algorithm of Hanasaki et al. (2006) with minor modifications by Döll et al. (2009). The annual reservoir release is a function of long-term average annual reservoir inflow, the relative reservoir storage at the beginning of the operational year, and the difference between precipitation and evaporation over the reservoir surface. Subsequently, monthly reservoir releases are calculated depending on the downstream consumptive water use in each month.

Other dam types are operated based on an optimization scheme provided by van Beek et al. (2011). Depending on the dam type, an objective function is applied that maximizes electricity production by maximizing the hydrostatic pressure head to the turbines (hydropower dams), minimizes flood damages by minimizing overbank flows (flood control dams), and aims for a constant outflow by minimizing deviations from the annual mean (water supply and navigation dams). Furthermore, we considered different constraints that reserve sufficient storage capacity to accommodate larger floods for 7 days (flood protection) and to keep sufficient water in the reservoir to safeguard a minimum flow for at least 30 days (minimum flow provisions).

Given current reservoir storage and monthly inflow data of the upcoming year, the overall modeling strategy is to find the monthly target storages (and corresponding monthly reservoir releases) that ensure optimal functioning of the dam. This strategy was realized in WaterGAP3 by evaluating objective functions and constraints through deterministic dynamic optimization (Bellman, 1957) and discretizing reservoir storage by the Savarenskiy scheme (Savarenskiy, 1940) considering a discretization width of $2 \%$. At the beginning of each month, the accumulated objective function value is computed for the upcoming 12 months taking into account every possible combination of the discrete reservoir storage classes. The combination, which provides the most suitable value for the objective function without harming any constraint, determines the monthly target storages. As inflow data, forecasted monthly values are used derived from average simulated flows of the last 5 years (rather than simulated values for the future year). This prospective scheme reflects more realistically the hydrological situation, where water managers have to deal with uncertain forecast as well (van Beek et al., 2011). The monthly target storages together with the actual incoming flow are subsequently used to calculate the daily reservoir releases.

In this modeling study we used WATCH-Forcing-DataERA-Interim (WFDEI; Weedon et al., 2014) for climate input representing current conditions. The time series consists of a set of daily, $30 \times 30 \operatorname{arcmin}(\sim 50 \times 50 \mathrm{~km}$ at the Equator) gridded meteorological forcing data, which were simply disaggregated to the 5 arcmin resolution as required by the model.

\subsubsection{Simulation of modified flow regimes under climate change}

To simulate future flow regimes modified only by climate change, additional model runs were conducted (tier 2, Fig. 1) for the 2050s (represented by the time period 2041-2070). Here, WaterGAP3 was driven with bias-corrected, daily climate data from five different general circulation models (GCMs), namely GFDL-ESM2M, HadGEM2-ES, IPSLCM5A-LR, MIROC-ESM-CHEM, and NorESM1-M, provided by ISI-MIP (Hempel et al., 2013). We assumed climate drivers to follow the Representative Concentration Pathway leading to a radiative forcing (cumulative measure of human emissions of greenhouse gases from all sources) of $6.0 \mathrm{~W} \mathrm{~m}^{2}$ (RCP6.0). Current $\mathrm{CO}_{2}$ emissions are close to the upper end of the scenario range and RCP6.0 is a medium-high emission scenario with a global mean temperature increase of $2.2^{\circ} \mathrm{C}$ until the end of the century compared to 1986-2005 (Riahi et al., 2011). Within the future time frame the differences between the emission scenarios (as represented by the radiative forcing) are smaller than between scenarios based on different GCMs. Thus we considered climate forcing of five different GCMs but only one emission scenario in order to address the uncertainty of projected climatic conditions. Although model outcomes of tier 2 will not reflect future conditions due to not taking into account future water management, this model experiment supports the identification of the sole effect of climate change on riparian wetland inundation. Therefore, we disabled dam operation and water use in these model runs.

\subsubsection{Simulation of reference flow regimes}

The aim of tier 3 was to simulate daily reference flow regimes reflecting near-natural conditions (Fig. 1). Hence, anthropogenic impacts such as dam operation and water use were disabled in these model runs. In order to be able to make comparisons with modified conditions, we conducted six different model runs for the reference period 1981-2010. We forced WaterGAP3 with WFDEI climate data to simulate reference flow regimes for the comparison with modified flows of tier 1 and with GCM data for the comparison with flow regimes of tier 2. Land cover data were derived from the Global Land Cover Characterization map (GLCC; USGS, 2008) and for EU countries from the CORINE Land Cover map (CLC2000; EEA, 2004) and kept constant over the entire model simulations.

\subsubsection{Estimation of bankfull flow}

Bankfull flow was estimated in our approach for each grid cell by flood frequency analysis (tier 4, Fig. 1). We applied the partial duration series (PDS) approach taking into ac- 
Table 1. Thresholds for different levels of mean annual flood volume deviation $(\Delta)$ between modified and natural flow regimes (as suggested for global assessments by Hoekstra et al., 2011).

\begin{tabular}{|c|c|c|}
\hline $\begin{array}{l}\text { River } \\
\text { status }\end{array}$ & $\begin{array}{l}\text { Level of } \\
\text { modification }\end{array}$ & $\begin{array}{l}\text { Thresholds for reduction } \\
\text { in flood volume }\end{array}$ \\
\hline A & none/slightly & $\Delta \leq 20 \%$ \\
\hline B & moderately & $20 \%<\Delta \leq 30 \%$ \\
\hline $\mathrm{C}$ & significantly & $30 \%<\Delta \leq 40 \%$ \\
\hline $\mathrm{D}$ & seriously & $\Delta>40 \%$ \\
\hline
\end{tabular}

count 30-year time series of daily discharge data modeled by WaterGAP3, an increasing threshold censoring procedure, a declustering scheme, and the generalized Pareto distribution. In the PDS, bankfull flow is determined by a return period of 0.92 years. The approach including a validation of bankfull flow estimates against observed conditions is described in detail by Schneider et al. (2011a). Results of this study show that bankfull flow can be reasonably simulated by WaterGAP3 with a high model efficiency $\left(E_{1}=0.71\right)$ and weighted correlation $\left(\omega r^{2}=0.90\right)$ as well as a systematic overestimation of $22.8 \%$.

\subsubsection{Assessment of overbank flow modifications}

We used the flood volume (i.e., the cumulative amount of daily discharge above bankfull) as a measure of the extent of flooding in tier 5 (Fig. 1) which was determined as the long-term annual mean over the 30 -year time period. The percentage change in flood volume between the modified and reference flow regimes describes the anthropogenic impact on floodplain inundation. Climate change impacts on flow regimes are presented as the ensemble median, which reflects the direction of change of at least three out of the five selected GCMs. The entire approach was carried out for each single grid cell of the global 5 arcmin raster, but only grid cells associated with riparian wetlands were examined further.

In order to evaluate the ecological consequences of flood volume alterations, thresholds needed to be defined. So far no generalizable relationships between flow alteration and ecological impact are available for large-scale assessments. Therefore we applied "thresholds for potential concern" (Hoekstra et al., 2011) for the deviation $(\Delta)$ in flood volume between the modified and reference flow regimes in order to distinguish distinct levels of modification (Table 1). These thresholds are based on the "presumptive standard" suggested by Richter et al. (2012) for daily flow alterations and likely indicating moderate to major changes in ecosystem structure and functions as well as initial thoughts from some water resource experts to set a global standard on eFlow requirements, though it has to be considered in our assessment that small reductions in flood volume can already result in large decreases in the extent of area flooded (Taylor et al., 1996; Kingsford, 2000; Tockner and Stanford, 2002).
Table 2. Defined impact on a riparian wetland due to new dam initiatives in the upstream area.

\begin{tabular}{llr}
\hline $\begin{array}{l}\text { Number of major } \\
\text { dam initiatives }\end{array}$ & $\begin{array}{l}\text { Potential } \\
\text { impact }\end{array}$ & $\begin{array}{r}\text { Number of } \\
\text { affected wetlands }\end{array}$ \\
\hline 0 & NONE & 63 \\
$1-12$ & MED & 16 \\
$28-276$ & HIGH & 14 \\
\hline
\end{tabular}

In general it can be expected that the greater the deviation from natural conditions, the greater the expected ecological impact (Poff and Hart, 2002; Magilligan and Nislow, 2005). Quantitative relationships between peak flows and ecosystems are provided, e.g., by Wilding and Poff (2008) for rivers in the US state of Colorado. In their study, riparian vegetation responds with a maximum change of $12 \%$ in community composition for each $10 \%$ reduction in peak flows. Consequently, a reduction of $40 \%$ in flood volume, which indicates a serious modification in our analysis, could lead to a $48 \%$ change in riparian vegetation. Stream invertebrates, in turn, respond exponentially. A $40 \%$ change in peak flow may cause a maximum response of $54 \%$ change in invertebrates.

\subsection{The qualitative assessment of threats}

In order to evaluate further impairments in riparian wetland flooding in the coming decades, we conducted a qualitative assessment. The qualitative assessment addresses (i) future dam construction and (ii) the capacity to act, which is required to respond to ecological threats caused by flow regime alterations.

\subsubsection{Future dam construction}

Besides climate change, the construction of new dams will further modify flood pulses and, thus, put additional pressure on riparian wetlands. Therefore, for each selected site we determined the number of all upstream dam projects which are over 10 megawatts in capacity and were planned, proposed or under construction as of July 2014 (Petersen-Perlman, 2014). A number of sources were used to build this dataset: the United Nations Framework Convention on Climate Change's Clean Development Mechanisms (http://cdm.unfccc.int), International Rivers, and other organizations' websites known to fund dam construction (e.g., World Bank). If no dam initiatives were found in the upstream area, we assigned no impact. The remaining sites were divided into two groups to define a medium (1-12 dam initiatives) and high (28-276 dam initiatives) impact (Table 2). The cutoff threshold between medium and high impact was chosen with the intention to get two almost equally sized groups of affected wetlands and to respect the large gap between 12 and 28 upstream dams. 
Table 3. Water availability for ecological allocations defined by means of the number of months with water scarcity upstream of the Ramsar site.

\begin{tabular}{ll}
\hline $\begin{array}{l}\text { Number of months } \\
\text { with water scarcity }\end{array}$ & $\begin{array}{l}\text { Water availability for } \\
\text { ecological allocation }\end{array}$ \\
\hline $6-12$ & LOW \\
$2-5$ & MED \\
$0-1$ & HIGH \\
\hline
\end{tabular}

\subsubsection{Capacity to act}

The implementation of counteractive measures is a complex task and depends on the local capacity to act. In order to assess that capacity for each site, we calculated two subindicators.

The first sub-indicator addresses the availability of water for ecological allocations. Flood pulse provisions especially require a relatively large amount of water at a specific time of the year. However, in some regions, water use alone can have a strong impact on the river flow regime. For example, the outflow of the Colorado and Murray-Darling rivers is reduced by water use to $<1$ and $36 \%$, respectively, of its natural flow (Jolly, 1996; Cushing and Allan, 2001). A high level of water scarcity in the upstream area indicates high water resource competition between different water use sectors and reduces the potential to allocate adequate amounts of water for ecological requirements. Water scarcity was defined following the approach of Hoekstra et al. (2012), who suggested that no more than $20 \%$ of monthly river discharge should be depleted by consumptive water use to maintain river ecosystem integrity. Depending on the average number of months per year with water scarcity (i.e., a consumptionto-availability ratio $>0.2$ ) in the upstream area, water availability for ecological purposes was determined (Table 3 ). The cutoff thresholds for low (6-12 months), medium (25 months), and high (0-1 month) water availability were arbitrarily chosen.

The second sub-indicator addresses the legal and institutional framework in place, and distinguishes between transboundary and non-transboundary upstream areas. For the latter, the sub-indicator depicts whether the country where the riparian wetland is located has legal provisions or official recommendations for the establishment of eFlows (yes) or not (no). Having a legal provision is an important first step for setting strategic goals, advocating ecological water requirements with stakeholders, securing planning resources, and promoting eFlow implementation (Le Quesne et al., 2010). However, it is no guarantee that eFlows will actually be established in practice, enforced, or adequate. As most of this information on legal eFlow provisions was available in qualitative terms, we introduce a simple yes-no query to our capacity to act indicator. In particular, no quantitative information on eFlow provisions was found for the management of
Table 4. Institutional capacity in place in transboundary upstream areas of riparian wetlands based on formal arrangements such as international water treaties, river basin organizations, legal eFlow provisions, and specific treaty provisions.

\begin{tabular}{ll}
\hline Score & Institutional capacity \\
\hline $0-2$ & LOW \\
$>2-4$ & MED \\
$>4-6$ & HIGH \\
\hline
\end{tabular}

dams. The main sources of information for this sub-indicator were OECD (2015), Benítez Sanz and Schmidt (2012), Le Quesne et al. (2010), and the FAO Water Lex Legal Database (FAO, 2015).

In transboundary upstream areas the sub-indicator takes into account five parameters as the complexity of water management increases. Here, we measured formal institutional capacity by (i) the presence of river basin organizations (RBOs), (ii) at least one relevant treaty, and specific treaty provisions such as (iii) a water allocation mechanism, (iv) a conflict resolution mechanism, and (v) flow variability management. Formal arrangements governing transboundary river basins, in the form of international water treaties and RBOs, can be particularly instrumental in managing disputes among different stakeholders involved in water resource management. The greater the institutional capacity, the higher the potential for eFlow allocations. Institutional frameworks can determine targets, responsible authorities, reoperation strategies, reallocation of water shares, monitoring efforts, and consequences of assessment outcomes (Le Quesne et al., 2010; Pahl-Wostl et al., 2013). For the calculation of this sub-indicator, we divided the upstream areas into basin-country units (BCUs, i.e., the portion of a country within a river basin shared by two or more countries). For each of the five parameters present at BCU level, one point was given, allowing for a score ranging from zero to five. In order to assign a score to each wetland reflecting upstream transboundary institutional capacity, we aggregated and weighted the scores of all upstream BCUs based on the contribution of each BCU to the runoff of the total upstream area. We gave an additional point in case the country where the wetland is located has legal provisions or official recommendations for the establishment of eFlows. The scores were then grouped into three classes describing a low, mid, and high institutional capacity (Table 4). All underlying data were obtained from De Stefano et al. (2012) and complemented with data embedded in international RBOs (Schmeier, 2014). 


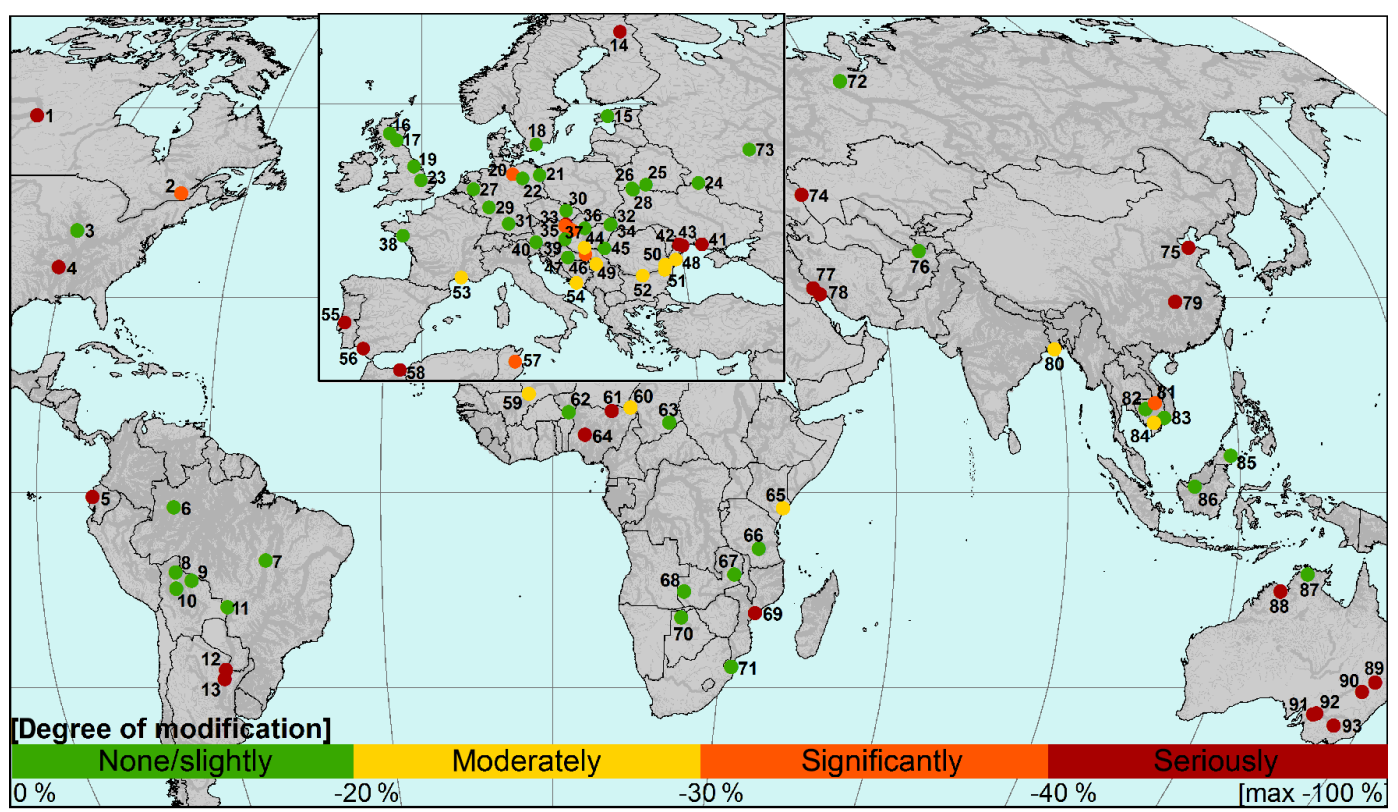

Figure 2. Global map of overbank flow alterations for selected riparian wetlands of international importance (nos. 1-93) as a consequence of current water resource management.

\section{Results}

\subsection{Quantitative analysis}

\subsubsection{Overbank flow alterations caused by current water resource management}

Figure 2 shows the degree of alteration in flood volume at the 93 wetland study sites caused by current (1981-2010) water management practices. When comparing modified to reference flow regimes, every second site $(51 \%)$ is impaired by at least moderately reduced flood volumes in our simulations. Almost every third site (29\%) is seriously and a further $8 \%$ are significantly affected by the flow regime modifications. Seriously affected sites occur on all continents, but particularly in Australia, China, North America, and the Iberian Peninsula, as well as at rivers that drain into the Black Sea (e.g., Dnieper and Dniester rivers) or the Persian Gulf (e.g., Tigris and Karun rivers). We found that dams for hydropower generation are the most frequent dam type in almost onethird of the selected upstream areas, followed by irrigation dams in one-quarter of the upstream areas. However, irrigation dams are the most frequent dam type in almost half of the cases $(48 \%)$, when only wetlands with seriously modified inundation patterns are regarded.

In Australia, five (nos. 89-93) of six vulnerable sites are located in the Murray-Darling basin. In their upstream areas more than $100 \%$ of the annual flow can be stored in reservoirs, indicating a high impact on flow regulation, which was also found by Grill et al. (2015). Intense agricultural irrigation is responsible for the highest water withdrawals and ir- rigation dams are the most frequent dam type in almost all upstream areas. This is underlined by Kingsford (2000), who reported that many floodplains in the Murray-Darling basin have turned into terrestrial ecosystems.

At the Volga River, the construction of dams for hydropower and navigation during the Soviet Union era substantially altered the flow regime, which seriously influences the dynamics of the Volga Delta (no. 74) in our analysis. This finding is in line with other studies. Khublaryan (2000) reported that mean high water flow decreased from 67 to $42 \%$ of the annual flow in the Lower Volga River due to river regulation. Middelkoop et al. (2015) found that dam operation caused a decrease in magnitude and duration of spring peak flow in the Lower Volga.

Nine of the analyzed sites are located along the Danube River, for which we identified slightly (no. 31), moderately (nos. 44, 48, 50, 51, and 52) and significantly (nos. 35, 37, and 46) reduced flood volumes. Despite numerous dams, the lower storage capacities cause the Danube River to be more affected by fragmentation than flow regulation, as also shown by Grill et al. (2015).

We found the lowest number of vulnerable wetlands in South America and Africa. In South America many riparian wetlands possess only slightly modified inundation patterns. Only a few large dams are located in upstream areas, and many river reaches, especially in the Amazon basin, are still in pristine condition (see also Tockner and Stanford, 2002). Nevertheless, seriously modified inundation patterns exist as well at three (nos. 5, 12, and 13) of nine selected study sites located in Ecuador and Argentina. In Africa, about half of the sites are not or only slightly affected under current condi- 


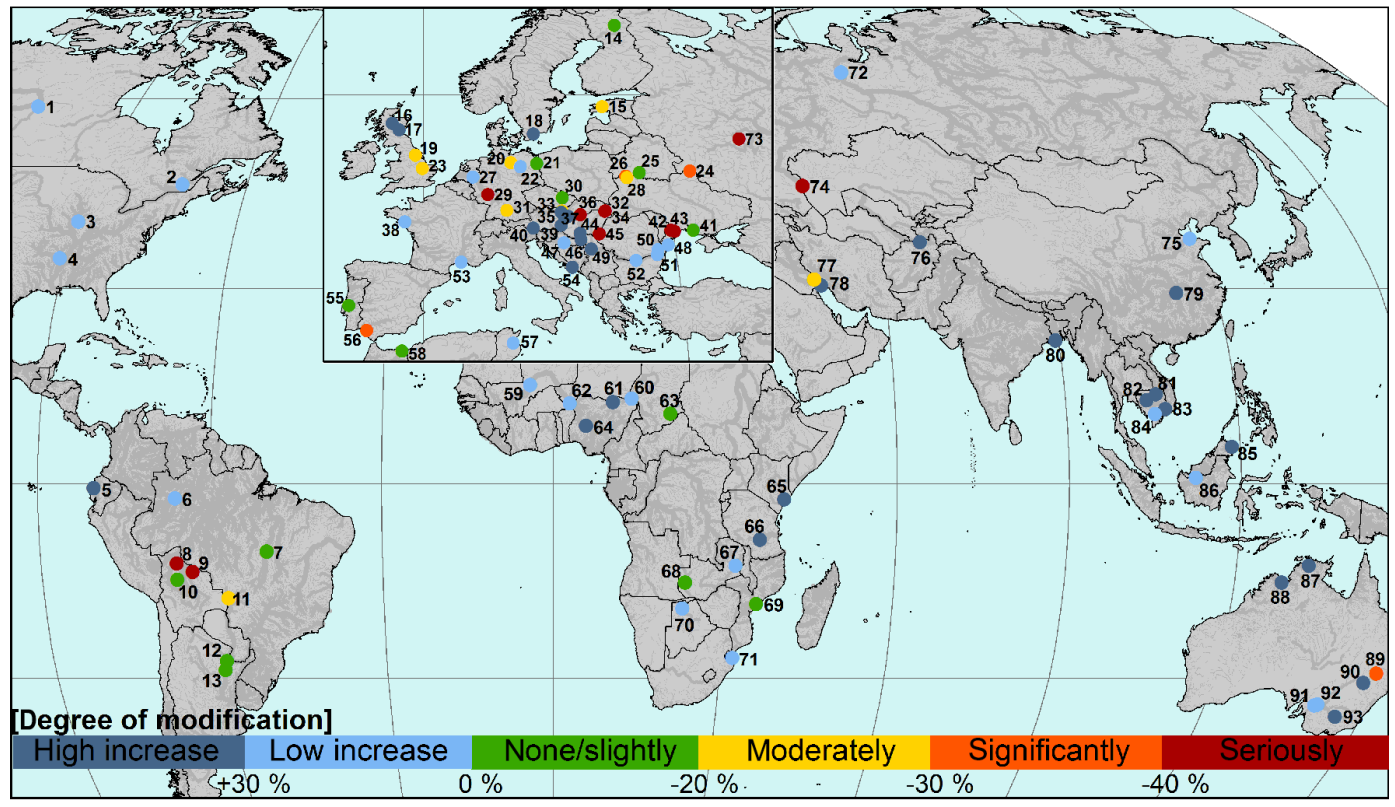

Figure 3. Global map of overbank flow alterations for selected riparian wetlands of international importance (nos. 1-93) as a consequence of the exclusive effect of climate change in the 2050s.

tions. However, one-third of the African sites are impaired by seriously or significantly altered overbank flow events. These sites are located in Morocco, Tunisia, Mozambique, and Nigeria. The threat to Nigeria's wetlands is also reported by Uluocha and Okeke (2004) inter alia due to population pressure and dam construction.

\subsubsection{Overbank flow alteration due to climate change}

In the future climate change is likely to further modify river flow regimes, as indicated by the model results driven by five GCM projections. According to the ensemble median, the average flood volume is expected to decrease at $41 \%$ of the sites in the 2050s due to the exclusive effect of climate change (Fig. 3). At $16 \%$ of the sites, reductions are significant or even serious (i.e., $>30 \%$ ). Overall two spatial hotspots could be identified where flood pulses are likely to be reduced under climate change, namely eastern $\mathrm{Eu}-$ rope/western Asia as well as South America below the Amazon River. These WaterGAP3 results are in line with Dankers et al. (2013), who modeled changes in peak flows at the end of this century by nine global hydrology models.

In Europe, most sites of concern are located in eastern Europe, i.e., in the Ukraine (nos. 24, 26, and 43), Hungary (nos. 32 and 36), Slovakia (no. 34), Moldova (no. 42), and Romania (no. 45), but also in Spain (no. 56) and Germany (no. 29). Climate change will induce an additional threat for three of the sites (nos. 42, 43, and 56) which already experience seriously or significantly reduced flood volumes under current water management practices. In Asia, wetlands affected by reduced flooding under climate change are located in Russia (nos. 73 and 74) and Iraq (no. 77). Flood pulses are already seriously reduced under current water management at two of them (nos. 74 and 77). The expected reduction in wetland inundation in eastern Europe and western Asia in the future can be explained by changes in snowmelt. In these two regions characterized by continental climate, global warming is likely to cause a reduction in snow cover resulting in lower and earlier snowmelt-induced flood peaks in spring as found by Schneider et al. (2011b, 2013). Moreover, analyses of streamflow trends in European Russia indicate that spring flows have been decreasing since the mid1970s (Georgiyevsky et al., 1995, 1996, 1997).

Increasing flood volumes, in contrast, can be found at $51 \%$ of the selected riparian wetlands under climate change conditions. The rise in flood volume is expected to be higher than $30 \%$ in the 2050 s at almost every third $(30 \%)$ site. Those wetlands tend to be located closer to the coast and especially in Southeast Asia, southeastern Europe, Scotland, western Africa, Tanzania, and Kenya. In the analysis of Dankers et al. (2013), increases in flood hazard were projected consistently for Southeast Asia.

\subsection{Qualitative analysis}

\subsubsection{Future dam construction}

New dam initiatives have the potential to further impair riparian wetland flooding. New dams are currently planned or under construction in the upstream areas of one-third of the selected riparian wetlands (Fig. 4). In agreement with results of Zarfl et al. (2014), extensive dam construction is on 


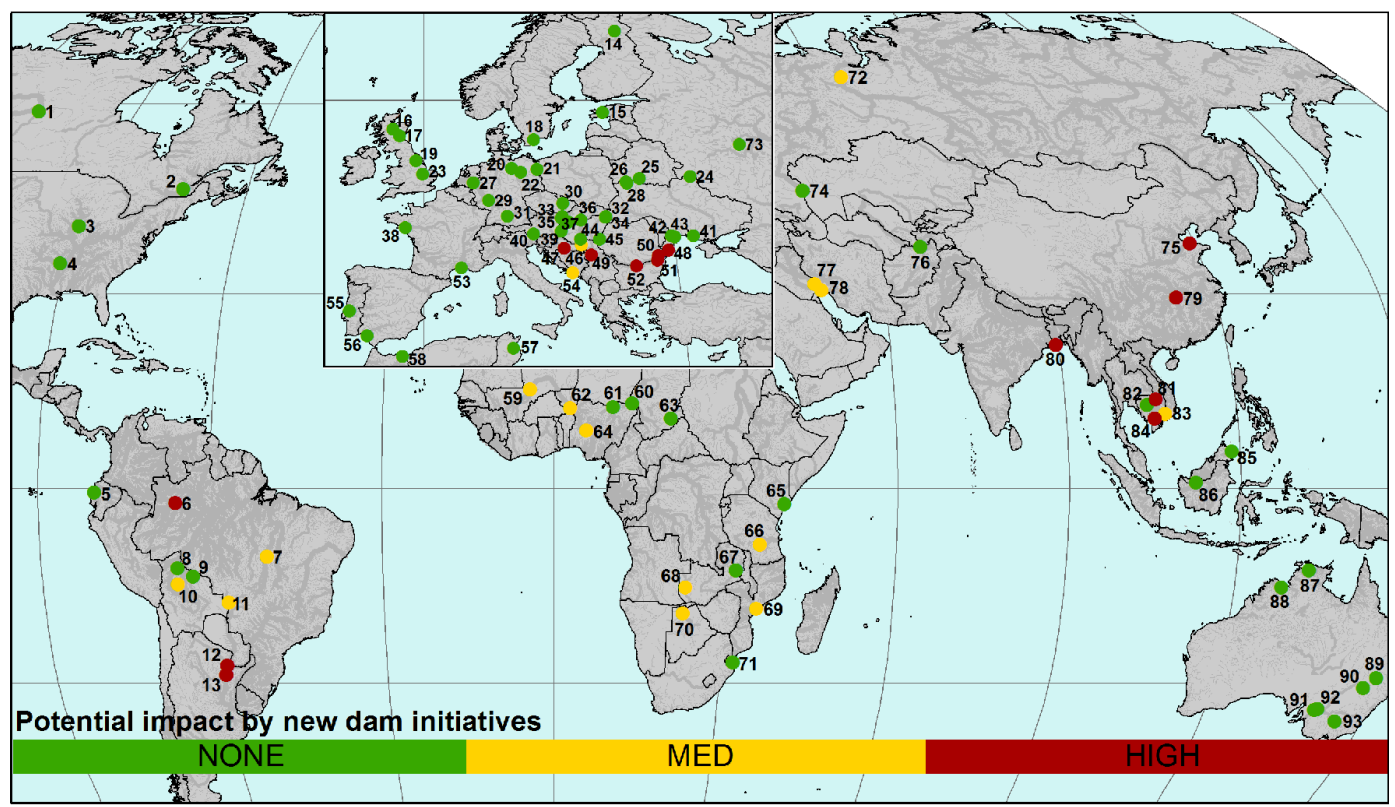

Figure 4. Potential impact of new dam initiatives taking into account dams currently planned or under construction in the upstream area of each riparian wetland.

the way, particularly in areas upstream of South American $(67 \%)$ and Asian (60\%) wetlands. We found that a large impact is likely in the upstream areas of wetlands located in the basins of Amazon, Parana, and Paraguay, as well as Yangtze, Yellow, Mekong, and Ganges-Brahmaputra. Riparian wetlands in China (nos. 75 and 79) and Argentina (nos. 12 and 13) are already characterized by seriously reduced flood volumes under current water management conditions. Dams are also planned or under construction upstream at about half $(47 \%)$ of the selected African sites, although the number of dams is relatively small in most upstream areas. Analyzing future trends for riverine floodplains, Tockner and Stanford (2002) also concluded in their assessment that in South America, Asia, and Africa, many floodplains will become reduced in size or even disappear in the future.

While a high number of dams have been constructed in North America and Australia in the last century, no further dams are planned or under construction upstream of the selected Ramsar sites. This is also the case for most parts of Europe, but a high number of new dams could be constructed upstream of riparian wetlands located in the Balkan Peninsula (i.e., in Croatia, Serbia, Bulgaria, and Romania), further threatening riparian wetlands in the lower Danube basin.

\subsubsection{Capacity to act}

Implementing counteractive measures requires that (i) sufficient water is available to satisfy water demands of different water use sectors and (ii) institutional arrangements are in place, enabling the establishment of eFlows. Considering these two factors, Fig. 5 displays the capacity to act in the upstream area for each riparian wetland.

Our analysis shows that the highest competition for water exists in the upstream area of the Lake Chad Wetlands (Nigeria) followed by wetlands of the Murray-Darling (Australia), Schatt al-Arab (Persian Gulf), Tana (Kenya), Moulouya (Morocco), and Yellow (China) River basins, where water scarcity occurs upstream in 6 to 10 months of the year on average. Lake Chad lost one-tenth of its size in the last 40 years (Uluocha and Okeke, 2004) and the United Nations Environment Programme stated that human water use is responsible for about half of the decrease (UNEP, 2008), which supports our finding. eFlow applications might also be challenging in the Iberian Peninsula as water availability for ecological purposes is rated medium, with water scarcity occurring on average in 5 months of the year due to high water requirements for agricultural irrigation.

Globally, normative eFlow provisions are considered in the national or State Water Act at about $50 \%$ of the selected Ramsar sites. The highest percentage of sites without normative eFlow provisions occurs in Asia (87\%) and Africa $(80 \%)$. The lowest values for formal institutional capacity became obvious in the transboundary upstream areas of wetlands located in the Ukraine (nos. 24 and 41), Belarus (no. 25), and Russia (no. 72). In this study, eastern Europe and western Asia were identified as hotspot regions where climate change is likely to reduce flood pulses in the future. Thus, a high formal institutional capacity would be of importance here to conserve riparian wetlands and allocate water to different water users. 


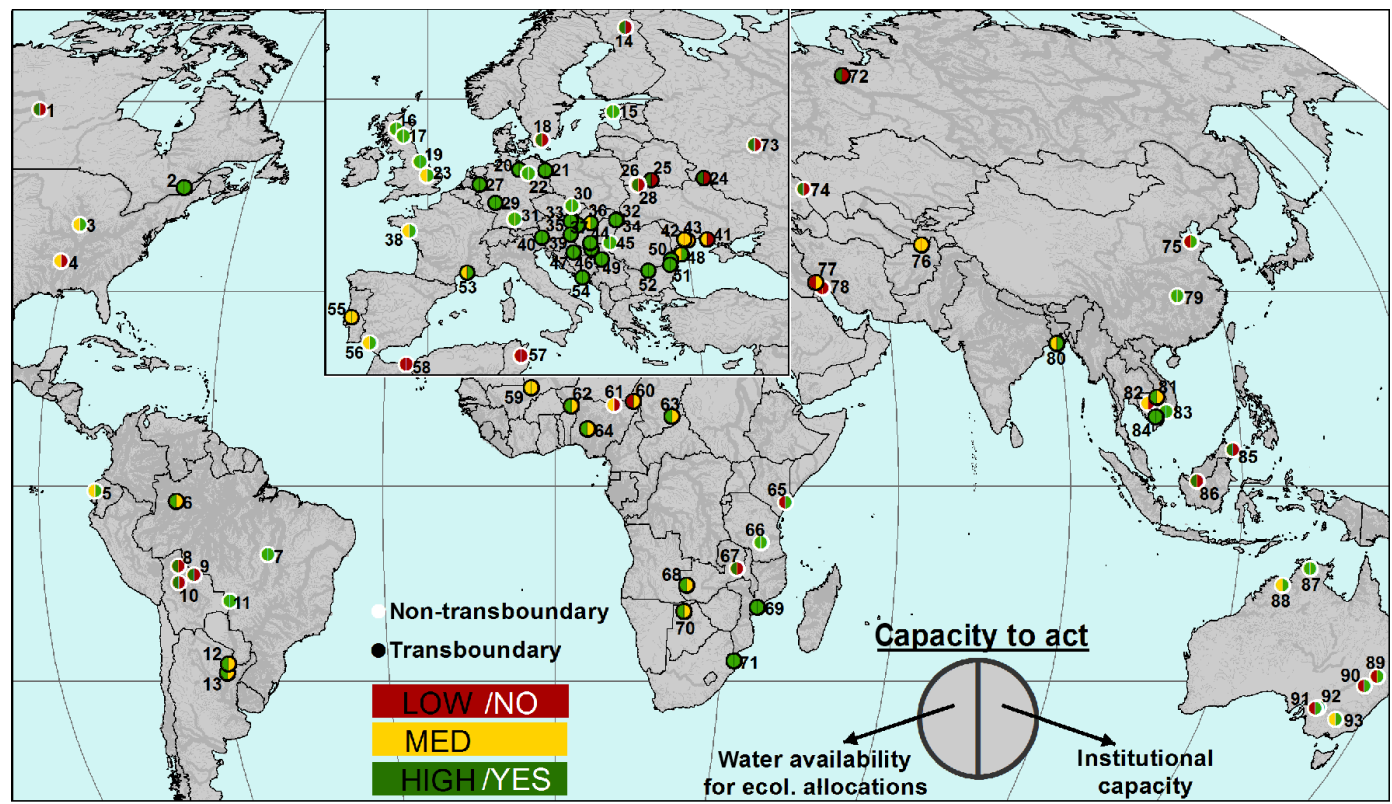

Figure 5. Current capacity to act with regard to anthropogenic flow regime modifications for selected riparian wetlands. The left semicircle represents the water availability for ecological allocations, while the right semicircle characterizes the institutional capacity in the upstream area. For wetlands with a non-transboundary upstream area (white border), the right semicircle represents the presence or absence of legal provisions or official recommendation to establish eFlows.

Considering both sub-indicators, the lowest values for capacity to act were found for riparian wetlands located in northern Africa (nos. 57 and 58), northeastern Nigeria (nos. 60 and 61), as well as at the Dnipro River Delta (no. 41) and the Persian Gulf (nos. 77 and 78). Detailed results for all indicators and wetlands are listed in Sect. S2.

\section{Discussion}

Currently, the concept of eFlows is transitioning from an era of ecosystem integrity and conservation at single river reaches to a period of globalization, where regional studies are complemented by global water assessments that cover large-scale developments. The main reasons are increasing threats at global scales (e.g., global warming) and the associated pace of ecosystem destruction, but more sophisticated global hydrology models are also available now (Poff and Matthews, 2013). In this study, we applied the WaterGAP3 global modeling framework, which has been further improved in recent years to model specific flow events such as floods. WaterGAP3 is a state-of-the-art global water model that performs well compared to other global and regional models (Beck et al., 2016; Eisner et al., 2017).

Despite the high number of dams (>6000) operated in WaterGAP3, our results for the impacts related to water resource management should be regarded as an underestimation as only larger dams from a global dataset (GRanD, Lehner et al., 2011) are taken into account. The aggregated effect of remaining smaller dams has an impact on floodplain inundation as well (Rosenberg et al., 2000), so it can be assumed that the impacts are even higher for some wetlands.

Our analysis is based on dam operation rather than reservoir capacity and river fragmentation. WaterGAP3 operates dams by dynamic optimization schemes taking into account various objective functions and constraints. Since no global dataset exists that describes specific operation rules or management strategies of individual dams, the dam operation module as part of WaterGAP3 considers generic operation schemes reflecting the main purpose of each dam. Thus, the performance of our dam module can be regarded as lower compared to detailed reservoir models using site-specific information. Accordingly, eFlow provisions that are already enforced in reality are also not acknowledged in the model. Therefore our screening tool could flag vulnerable wetlands that are, at least to some degree, protected by eFlow provisions in practice. For example, eFlow provisions are part of Australian law and have also been defined for floodplain wetlands of the Murray-Darling basin (Poff and Matthews, 2013). Yet eFlows are defined at only a tiny fraction of rivers worldwide and in most cases are restricted to low flows (Poff et al., 2009; Richter et al., 2012), so that most wetlands remain vulnerable to flow regime modifications. Our study benefits from the qualitative assessment where we collected information on legal eFlow provisions from the related national or State Water Act, which we combined with our quantitative model outcomes. Legal eFlow provisions are regarded as a first important step for promoting eFlow imple- 
mentation. However, they do not guarantee that eFlows will actually be established in practice, enforced, or adequate, and hence could not be considered in the model's operation scheme.

We used flood volume as a proxy indicator for the extent of flooding. Further improvements of the screening tool will address the implementation of floodplain storages in WaterGAP3 based on an elevation model on sub-grid scale. This will enable a better estimation of change in the extent of flooding due to flow regime alterations. In order to distinguish between different wetland types, it would be useful that future global wetland datasets provide more information on the wetland's main source of water as done in the European wetland geodatabase of Okruszko et al. (2011).

We stress that global-scale modeling is limited by the quality of all input data used in our calculations. In wealthier countries data availability and verification is often more advanced. Hence, a bias of the model performance can be expected, with a higher uncertainty in data-poor regions. However, our global-scale modeling approach allows transfer of knowledge to these regions by identifying hotspots of risk where further hydro-ecological research can be directed.

The implementation of appropriate counteractive measures is likely to be most urgent for the identified hotspots of current and future threats. Those measures encompass adaptive integrated dam management that reconciles interests of different water use sectors, improved flood management plans, water-use-efficiency enhancement, and sophisticated eFlow provisions, e.g., according to the Block Building Methodology (BBM; Tharme and King, 1998) or the Basic Flow Methodology (BFM; Palau and Alcazar, 2012). These two methodologies take account of ecologically relevant flow elements such as flood pulses for riparian wetlands. Dam reoperation strategies aiming at ecosystem restoration depend on the dam's main operating purpose (Watts et al., 2011). In our assessment hydropower dams were the most frequent dam type in the upstream areas of riparian wetlands. However, irrigation dams dominate in the upstream areas of seriously affected sites. Consequently, notably for irrigation and hydropower dams, innovative and integrative operating rules need to be developed, maintaining global food security and economic benefits while at the same time releasing eFlows for ecosystem health and biodiversity.

Depending on the location, climate change will increase or decrease floodplain inundation in the future. In our simulations, two hotspots (eastern Europe/western Asia as well as central South America) were identified with reduced floodplain wetland inundation under climate change. Especially these sites could benefit from achieving climate targets set in international agreements. Further application of the screening tool presented in this study could take into account a higher number of GCM projections as well as scenarios describing future socio-economic developments. Outcomes could be used for a comprehensive uncertainty analysis in order to make statements for each wetland about the prob- ability and degree of change. Depending on the RCP, projected global mean temperature is likely to increase between 0.3 and $4.8^{\circ} \mathrm{C}$ until the end of the 21 st century relative to 1986-2005 (IPCC, 2014). For time horizons beyond 2050, it would also be advisable to select climate change projections representing more than one RCP to provide insight into a full range of possible future developments. As the goal of this paper is to demonstrate the screening tool, only results for the ensemble median of five GCMs were presented. The model results on changes in overbank flows as obtained from the five different GCMs are included in Sect. S3.

Regarding sites with simulated increasing flood volumes, it is uncertain from the global perspective whether the increased flood volume benefits the wetland or generates flood damages for people. The latter, in turn, would be an incentive to build more dams for flood control (Poff and Matthews, 2013). In particular it needs to be assured that high-flow pulses do not expose people to flood risk and damage. In general, all wetlands could benefit from improved flood management plans taking non-structural measures into account (Sparks, 1995). For example, restoring river floodplains and dead stream branches minimizes flood damages and reduces flood-control storages in reservoirs. This measure would increase the potential to allocate more water for hydropower generation, water supply, or eFlow provisions (Watts et al., 2011). Further measures encompass dyke relocation, buying land from farmers, defining maximum admissible dam releases for flood provisions, or establishing floodways that direct floodwater around human settlements.

Riparian wetlands are threatened by human-induced flow regime modifications, but also depend on society's capacity to act to prevent or reduce these modifications through the implementation of counteractive measures. These two dimensions together have not yet been considered in global assessments of hydrological threats to riparian wetlands. In order to fill this gap, our approach addresses both dimensions and combines qualitative information on the capacity to act with quantitative hydrological model results. In riparian wetlands that are located in countries where the capacity to act is limited by a low institutional capacity, the acknowledgement of ecological water requirements in its legislation could be assumed to be an important first step in eFlow implementation. This would show that ecological water requirements are on the agenda of legislators and water practitioners, and hence helps in advocating acceptance of ecological water requirements. In general, the more countries depend on the available water resources within a river basin, the more challenging the implementation of eFlows is. Therefore, for all transboundary upstream areas, we aimed at investigating whether RBOs, international water treaties, and specific treaty provisions have already been put in place to manage disputes and water resource allocation among different water users. At riparian wetlands in transboundary river basins where institutional capacity is low, the establishment of such formal arrangements could be supportive of wetland conser- 
vation. While the institutional capacity indicator considers national laws, international treaties, and RBO agreements, it is important to stress that the presence of formal arrangements is no guarantee of effective enforcement in practice.

Our screening tool helps to identify riparian wetlands where the capacity to act is limited by, e.g., high water resource competition. Especially at sites suffering from water shortage in the upstream area, measures are likely to be required that increase water use efficiency (e.g., water recycling, technological innovations, dripping irrigation, changing crop mix, importing agricultural products, water metering or other incentives to save water) in order to reduce water abstractions and raise the amount of water that can be allocated for ecological requirements.

We assessed the threat of future dam construction to riparian wetlands globally. Because no comprehensive list of major dam initiatives (including storage capacities) is publicly available, we collected the number of dams that are currently planned, proposed, or under construction in upstream areas of riparian wetlands as a first indication of the threat of riparian wetland inundation. As a next step, new dam initiatives could be implemented in the WaterGAP3 model to quantitatively judge changes in flood volumes. This would account for operation, location in the upstream area, and storage volume of future dams, and thus improve analysis of future ecological and human water stress. Including the information on new dam initiatives in the model would be a huge step towards a comprehensive scenario assessment to quantitatively evaluate the combined effects of dam operation, water use, and climate change on river flow regimes. Additionally, riparian wetland inundation is also influenced by landuse changes (e.g., deforestation, land drainage, or sealing of large urban areas) and river construction (e.g., embankment, re-aligning, widening, or deepening). These influences interact with water resource management and climate change, but did not fall within the scope of this paper.

\section{Conclusions and outlook}

Freshwater demands of an exponentially growing world population, hydropower development as a new source of renewable energy, and projected climate change pose important challenges to the maintenance of riparian wetlands worldwide. Since riparian wetlands provide valuable ecosystem services and are disappearing at an alarming rate, assessing the alteration of ecologically important flood pulses addresses crucial research questions related to environmental, water, and flood management. Therefore, this study aimed at establishing a global screening tool to systematically identify hotspots and patterns of hydrological change and to flag riparian wetlands vulnerable to inundation regime modifications. The information provided by this tool can be useful for directing further hydro-ecological research that takes into account local information and expertise of site-specific ecological, social, and economic conditions.

A multitude of applications are possible with our proposed screening tool. The bankfull flow approach applied at grid cell level enables the assessment of all larger riparian wetlands worldwide and can be used to conduct a comprehensive global riparian wetland assessment. Considering the change in the extent of flooding, the quantification of specific ecosystem services from intact riparian wetlands could be performed. Examples comprise production of important resources such as wood, reed, hay, and fish, water purification by removing nutrients and toxins, as well as flood control and risk reduction for people, and how this is likely to change in the future under climate change and further dam construction. The WaterGAP3 integrated global modeling framework allows scenario assessment considering different drivers of global change in renewable freshwater resources by allocating water resources to different water use sectors and evaluating the respective consequences under different management targets. Overall, the screening tool based on quantitative and qualitative indicators could support policy makers at international level (e.g., at forums like UNEP, OECD, the European Union, the Convention on Wetlands of International Importance, and the Convention on Biological Diversity) in implementing global conservation efforts, targeting wetland conservation funds, planning of water infrastructure location and design, and balancing water allocations to humans and nature.

Data availability. Results of the quantitative analysis presented in Figs. 2 and 3 were generated using our own WaterGAP3 global modeling framework. Underlying data sources of the qualitative analysis presented in Figs. 4 and 5 are listed under the methodology section. The data are available from the corresponding author upon request.

\section{The Supplement related to this article is available online at https://doi.org/10.5194/hess-21-2799-2017- supplement.}

Competing interests. The authors declare that they have no conflict of interest.

Acknowledgements. Research funding for this study was partially provided by the Global Environment Facility Transboundary Water Assessment Programme (GEF TWAP, http://twap-rivers.org/) and is gratefully acknowledged. Data on riparian wetland location and extent were downloaded from the website of the Ramsar Convention Secretariat (http://www.ramsar.org/).

Edited by: N. Basu

Reviewed by: B. Neff and two anonymous referees 


\section{References}

Alcamo, J., Döll, P., Henrichs, T., Kaspar, F., Lehner, B., Rösch, T., and Siebert, S.: Global estimates of water withdrawals and availability under current and future "business-as-usual" conditions, Hydrol. Sci. J., 48, 339-349, 2003.

Allan, J. D., Palmer, M. A., and Poff, N. L.: Climate change and freshwater ecosystems, in: Climate Change and Biodiversity, Yale University Press, New Haven CT, 272-290, 2005.

Arthington, A. H., Bunn, S. E., Poff, N. L., and Naiman, R. J.: The challenge of providing environmental flow rules to sustain river ecosystems, Ecol. Appl., 16, 1311-1318, 2006.

aus der Beek, T., Flörke, M., Lapola, D. M., Schaldach, R., Voß, F., and Teichert, E.: Modelling historical and current irrigation water demand on the continental scale: Europe, Adv. Geosci., 27, 79-85, https://doi.org/10.5194/adgeo-27-79-2010, 2010.

Barbier, E. B. and Thompson, J. R.: The value of water: Floodplain versus large-scale irrigation benefits in northern Nigeria, AMBIO, 27, 434-440, 1998.

Bayley, P. B.: The Flood Pulse Advantage and the Restoration of River-Floodplain Systems, Regulated Rivers: Research \& Management, 6, 75-86, 1991.

Bayley, P. B.: Understanding Large River: Floodplain Ecosystems, BioScience, 45, 153-158, 1995.

Beck, H. E., van Dijk, A. I. J. M., de Roo, A., Dutra, E., Fink, G., Orth, R., and Schellekens, J.: Global evaluation of runoff from ten state-of-the-art hydrological models, Hydrol. Earth Syst. Sci. Discuss., https://doi.org/10.5194/hess-2016-124, in review, 2016.

Bellman, R. E.: Dynamic Programming, Princeton, NJ, Princeton University Press, 340 pp., 1957.

Benítez Sanz, C., and Schmidt, G.: Analysis of the implementation of Environmental Flows in the wider context of the River Basin Management Plans, Report, INTECSA-INARSA, available at: http://ec.europa.eu/environment/archives/water/implrep2007/ pdf/Waterabstractionanduse-Eflows.pdf (last access: 22 June 2015), 2012.

Chao, B. F., Wu, Y. H., and Li, Y. S.: Impact of artificial reservoir water impoundment on global sea level, Science, 320, 212-214, https://doi.org/10.1126/science.1154580, 2008.

Collier, M., Webb, R. H., and Schmidt, J. C.: Dams and Rivers A Primer on the Downstream Effects of Dams, US Geological Survey, Circular 1126, 108 pp., 1996.

Costanza, R., d'Arge, R., de Groot, R., Faber, S., Grasso, M., Hannon, B., Limburg, K., Naeem, S., O’Neill, R. V., Paruelo, J., Raskin, R. G., Sutton, P., and van der Belt, M.: The value of the world's ecosystems and natural capital, Nature, 387, 253-260, 1997.

Cushing, C. E. and Allan, J. D.: Streams: Their Ecology and Life, Academic Press, San Diego, CA, 89 pp., 2001.

Dankers, R., Arnell, N. W., Clark, D. B., Falloon, P. D., Fekete, B. M., Gosling, S. N., Heinke, J., Kim, H., Masaki, Y., Satoh, Y., Stacke, T., Wada, Y., and Wisser, D.: First look at changes in flood hazard in the Inter-Sectoral Impact Model Intercomparison Project ensemble, P. Natl. Acad. Sci. USA, 111, 3257-3261, https://doi.org/10.1073/pnas.1302078110, 2013.

De Stefano, L., Duncan, J., Dinar, S., Stahl, K., Strzepek, K. M., and Wolf, A. T.: Climate change and the institutional resilience of international river basins, J. Peace Res., 49, 193-209, 2012.
Dixon, M. J. R., Loh, J., Davidson, N. C., Beltrame, C., Freeman, R., and Walpole, M.: Tracking global change in ecosystem area: The Wetland Extent Trends index, Biol. Cons., 193, 27-35, https://doi.org/10.1016/j.biocon.2015.10.023, 2016.

Döll, P. and Zhang, J.: Impact of climate change on freshwater ecosystems: a global-scale analysis of ecologically relevant river flow alterations, Hydrol. Earth Syst. Sci., 14, 783-799, https://doi.org/10.5194/hess-14-783-2010, 2010.

Döll, P., Fiedler, K., and Zhang, J.: Global-scale analysis of river flow alterations due to water withdrawals and reservoirs, Hydrol. Earth Syst. Sci., 13, 2413-2432, https://doi.org/10.5194/hess-132413-2009, 2009.

Doocy, S., Daniels, A., Murray, S., and Kirsch, T. D.: The Human Impact of Floods: a Historical Review of Events 1980-2009 and Systematic Literature Review, PLOS Currents Disasters, 1, https://doi.org/10.1371/currents.dis.f4deb457904936b07c09daa, 2013.

Dynesius, M. and Nilsson, C.: Fragmentation and flow regulation of river systems in the Northern third of the world, Science, 266, 753-62, 1994.

EEA (European Environment Agency): Corine Land Cover 2000 - Mapping a decade of change Document Actions, Tech. Rep. Brochure No 4/2004, 2004.

Eisner, S.: Comprehensive evaluation of the WaterGAP3 model across climatic, physiographic, and anthropogenic gradients, dissertation, KOBRA Dokumentenserver, University of Kassel, Germany, available at: http://nbn-resolving.de/urn:nbn:de:hebis: 34-2016031450014 (last access: 6 June 2017), 2016.

Eisner, S., Flörke, M., Chamorro, A., Daggupati, P., Donnelly, C., Huang, J., Hundecha, Y., Koch, H., Kalugin, A., Krylenko, I., Mishra, V., Piniewski, M., Samaniego, L., Seidou, O., Wallner, M., and Krysanova, V.: An ensemble analysis of climate change impacts on streamflow seasonality across 11 large river basins, Climatic Change, 1-17, https://doi.org/10.1007/s10584016-1844-5, 2017.

FAO (Food and Agriculture Organization of the United Nations): FAO Water Lex Legal Database, http://www.waterlex.org/ waterlex-legal-database/, last access: 22 June 2015.

FAO (Food and Agriculture Organization of the United Nations): World Development Indicators, AQUASTAT data, available at: http://data.worldbank.org/indicator/ER.H2O.FWTL.K3 (last access: 20 January 2017), 2016.

Flörke, M., Bärlund, I., and Kynast, E.: Will climate change affect the electricity production sector? A European study, Water Climate Change, 3, 44-54, https://doi.org/10.2166/wcc.2012.066, 2012.

Flörke, M., Kynast, E., Bärlund, I., Eisner, S., Wimmer, F., and Alcamo, J.: Domestic and industrial water uses of the past 60 years as a mirror of socio-economic development: A global simulation study, Glob. Environ. Change, 23, 144-156, https://doi.org/10.1016/j.gloenvcha.2012.10.018, 2013.

Georgiyevsky, V. Y., Zhuravin, S. A., and Ezhov, A. V.: Assessment of trends in hydrometeorological situation on the Great Russian Plain under the effect of climate variations, in: Proceedings of American Geophysical Union, 15th Annual Hydrology Days, 47-58, 1995.

Georgiyevsky, V. Y., Yezhov, A. V., Shalygin, A. L., Shiklomanov, A. I., and Shiklomanov, I. A.: Evaluation of possible climate 
change impact on hydrological regime and water resources of the former USSR rivers, Russ. Meteorol. Hydrol., 11, 89-99, 1996.

Georgiyevsky, V. Y., Yezhov, A. V., and Shalygin, A. L.: An assessment of changing river runoff due to man's impact and global climate warming, in: River Runoff Calculations, Report at the International Symposium, UNESCO, 75-81, 1997.

GRDC: Long Term Mean Monthly Discharges and Annual Characteristics of Selected GRDC Stations, the Global Runoff Data Centre, Koblenz, Germany, 2004.

Gregory, S. V., Swanson, F. J., McKee, W. A., and Cummins, K. W.: An ecosystem perspective of riparian zones, BioScience, 41, 540-551, 1991.

Grill, G., Lehner, B., Lumsdon, A. E., MacDonald, G. K., Zarfl, C., and Liermann, C. R.: An index-based framework for assessing patterns and trends in river fragmentation and flow regulation by global dams at multiple scales, Environ. Res. Lett., 10, https://doi.org/10.1088/1748-9326/10/1/015001, 2015.

GWP (Global Water Partnership): Integrated water resource management in Central Asia: The challenges of managing large transboundary rivers, Technical Focus Paper, ISBN: 91-85321-99-0, 2014.

Haddeland, I., Heinke, J., Biemans, H., Eisner, S., Flörke, M., Hanasaki, N., Konzmann, M., Ludwig, F., Masaki, Y., Stacke, T., Tessler, Z. D., Wada, Y., and Wisser, D.: Global water resources affected by human interventions and climate change, Supporting Information, P. Natl. Acad. Sci. USA, 111, 3251-3256, 2014.

Hanasaki, N., Kanae, S., and Oki, T.: A reservoir operation scheme for global river routing models, J. Hydrol., 327, 22-41, 2006.

Hempel, S., Frieler, K., Warszawski, L., Schewe, J., and Piontek, F.: A trend-preserving bias correction - the ISI-MIP approach, Earth Syst. Dynam. Discuss., 4, 49-92, https://doi.org/10.5194/esdd-449-2013, 2013.

Hoekstra, A. Y., Chapagain, A. K., Aldaya, M. M., and Mekonnen, M. M.: The Water Footprint Assessment Manual: Setting the Global Standard, Earthscan, London, Washington, DC, ISBN 978-1-84971-279-8, 2011.

Hoekstra, A. Y., Mekonnen, M. M., Chapagain, A. K., Mathews, R. E., and Richter, B. D.: Global water scarcity: the monthly blue water footprint com- pared to blue water availability for the world's major river basins, P. Natl. Acad. Sci. USA, 109, 3232 3237, https://doi.org/10.1073/pnas.1109936109, 2012.

Hughes, F. M. R.: The ecology of African floodplain forests in semiarid and arid zones: a review, J. Biogeogr., 15, 127-140, 1988.

ICOLD (International Commission of Large Dams): World Register of Dams, Int. Comm, Large Dams, Paris, France, 2007.

IPCC: Climate Change 2014: Synthesis Report, Contribution of Working Groups I, II and III to the Fifth Assessment Report of the Intergovernmental Panel on Climate Change edited by: Core Writing Team, Pachauri, R. K., and Meyer, L. A., IPCC, Geneva, Switzerland, 151 pp., 2014.

Jolly, I. D.: The effects of river management on the hydrology and hydroecology of arid and semi-arid floodplains, in: Floodplain Processes, edited by: Anderson, M. G., Walling, D. E., and Bates, P. D., Chichester, UK, Wiley, 577-609, 1996.

Jonkman, S. N.: Global Perspectives on Loss of Human Life Caused by Floods, Nat. Hazard., 34, 151-175, 2005.

Junk, W. J. and Wantzen, K. M.: The Flood Pulse Concept: New Aspects, Approaches and Applications - An Update, in Welcomme, R., Petr, T., (eds.), Proceedings of the 2nd Large River Sympo- sium (LARS), Pnom Penh, Cambodia, Bangkok, RAP Publication, 117-140, 2004.

Junk, W. J., Bayley, P. B., and Sparks, R. E.: The flood pulse concept in river-floodplain systems, Can. Spec. Publ. Fish. Aquat. Sci., 110-127, 1989.

Kingsford, R. T.: Ecological impacts of dams, water diversions and river management on floodplain wetlands in Australia, Aust. Ecol., 25, 109-127, 2000.

Khublaryan, M. G.: Water Resources for Sustainable Development, with particular Reference to Russia, in: Encyclopedia of Life Support Systems (EOLSS), Vol. 1, Area Studies-Russia (Regional Sustainable Development Review, ISBN-978-1-84826074-0, 2000.

Laize, C. L. R., Acreman, M. C., Schneider, C., Dunbar, M. J., Houghton-Carr, H., Flörke, M., and Hannah, D. M.: Projected flow alteration and ecological risk for pan-European rivers, River Res. Appl., 30, 299-314, https://doi.org/doi.org/10.1002/rra.2645, 2014.

Lehner, B., Verdin, K., and Jarvis., A.: New Global hydrography derived from spaceborne elevation data, Eos. Trans. 89, 93-94, 2008.

Lehner, B., Liermann, C. R., Revenga, C., Vörösmarty, C., Fekete, B., Crouzet, P., Döll, P., Endejan, M., Frenken, K., Magome, J., Nilsson, C., Robertson, J. C., Rödel, R., Sindorf, N., and Wisser, D.: High-resolution mapping of the world's reservoirs and dams for sustainable river-flow management, Front. Ecol. Environ., 9, 494-502, https://doi.org/10.1890/100125, 2011.

Le Quesne, T., Kendy, E., and Weston, D.: The Implementation Challenge: Taking stock of government policies to protect and restore environmental flows, WWF and Nature Conservancy, http://awsassets.panda.org/downloads/the implementation_challenge.pdf (last access: 22 June 2015), 2010.

Lloyd, N., Quinn, G., Thoms, M., Arthington, A., Gawne, B., Humphries, P., and Walker, K.: Does flow modification cause geomorphological and ecological response in rivers?, a literature review from an Australian perspective, Technical report 1/2004, CRCFE, Canberra, 2004.

Magilligan, F. J. and Nislow, K. H.: Changes in hydrologic regime by dams, Geomorphology, 71, 61-78, 2005.

Maheshwari, B. L., Walker, K. F., and McMahon, T. A.: Effects of flow regulation on the flow regime of the River Murray, Australia, Regulated Rivers: Research \& Management, 10, 15-38, 1995.

McCully, P.: Silenced rivers: the ecology and politics of large dams, Zed Books, London, UK, 1996.

McDonald, R., Weber, K., Padowski, J., Flörke, M., Schneider, C., Green, P., Gleeson, T., Eckman, S., Lehner, B., Balk, D., Boucher, T., Grill, G., and Montgomery, M.: Water on an urban planet: urbanization and the reach of urban water infrastructure, Glob. Enviro. Change, 27, 96-105, 2014.

Middelkoop, H., Alabyan, A. M., Babich, D. B., and Ivanov, V. V.: Post-dam Channel and Floodplain Adjustment along the Lower Volga River, Russia, Geomorphic Approaches to Integrated Floodplain Management of Lowland Fluvial Systems in North America \& Europe, 245-264, https://doi.org/10.1007/9781-4939-2380-9_10, 2015.

Milly, P. C. D., Betancourt, J., Falkenmark, M., Hirsch, R. M., Kundzewicz, Z. W., Lettenmaier, D. P., and Stouffer, R. J.: Sta- 
tionarity Is Dead: Whither Water Management?, Science, 319, 573-574, https://doi.org/10.1126/science.1151915, 2008.

Moore, M.: Perceptions and interpretation of environmental flows and implications for future water resources management: a survey study, Thesis (MSc), Department of Water and Environment Studies, Linköping University, Sweden, 2004.

Naiman R. J., Décamps H., and Pollock, M.: The role of riparian corridors in maintaining regional biodiversity, Ecol. Appl., 3, 209-212, 1993.

Naiman, R. J., Bunn, S. E., Nilsson, C., Petts, G. E., Pinay, G., and Thompson, L. C.: Legitimizing fluvial ecosystems as users of water: an overview, Environ. Manage., 30, 455-467, https://doi.org/10.1007/s00267-002-2734-3, 2002.

Nilsson, C. and Berggren, K.: Alterations of riparian ecosystems caused by river regulation, Bioscience, 50, 783-792, 2000.

Nilsson, C., Reidy, C. A., Dynesius, M., and Revenga, C.: Fragmentation and flow regulation of the world's large river systems, Science 308, 405-408, 2005.

Nislow, K. H., Magilligan, F. J., Fassnacht, H., Bechtel, D., and Ruesink, A.: Effects of hydrologic alteration on flood regime of natural floodplain communities in the upper Connecticut River, J. Am. Water Resour. Assoc., 38, 1533-1548, 2002.

Nohara, D., Kitoh, A., Hosaka, M., and Oki, T.: Impact of Climate Change on River Discharge Projected by Multimodel Ensemble, J. Hydrometeorol., 7, 1076-1089, 2006.

Norris, R. H. and Thoms, M. C.: What is river health?, Freshwater Biol., 41, 197-209, 1999.

OECD (Organisation for Economic Co-operation and Development): Water Resources Allocation: Sharing Risks and Opportunities, OECD studies on Water, OECD Publishing, Paris, https://doi.org/10.1787/9789264229631-en, 2015.

Okruszko, T., Duel, H., Acreman, M., Grygoruk, M., Flörke, M., and Schneider, C.: Broad-scale ecosystem services of European wetlands - overview of the current situation and future perspectives under different climate and water management scenarios, Hydrol. Sci. J., 56, 1501-1517, 2011.

Pahl-Wostl, C., Arthington, A., Bogardi, J., Bunn, S. E., Hoff, H., Lebel, L., Nikitina, E., Palmer, M., Poff, L. N., Richards, K., Schlüter, M., Schulze, R., St-Hilaire, A., Tharme, R., Tockner, K., and Tsegai, D.: Environmental flows and water governance: managing sustainable water uses, Curr. Opin. Environ. Sust., 5, 341-351, https://doi.org/10.1016/j.cosust.2013.06.009, 2013.

Palau, A. and Alcazar, J.: The basic flow method for incorporating flow variability in environmental flows, River Res. Appl., 28, 93102, 2012.

Pastor, A. V., Ludwig, F., Biemans, H., Hoff, H., and Kabat, P.: Accounting for environmental flow requirements in global water assessments, Hydrol. Earth Syst. Sci., 18, 5041-5059, https://doi.org/10.5194/hess-18-5041-2014, 2014.

Petersen-Perlman, J. D.: Mechanisms of cooperation for states' construction of large-scale water infrastructure in transboundary river basins, PhD Dissertation, Oregon State University, USA, 2014.

Petts, G. E.: Impounded Rivers: Perspectives for Ecological Management, John Wiley and Sons, Chichester, England, 326 pp., 1984.

Poff, N. L. and Hart, D. D.: How Dams Vary and Why It Matters for the Emerging Science of Dam Removal, BioScience, 52, 659$738,2002$.
Poff, N. L. and Matthews, J. H.: Environmental flows in the Anthropocence: past progress and future prospects, Current Opinion in Environmental Sustainability, 5, 667-675, 2013.

Poff, N. L. and Zimmerman, J. K. H.: Ecological responses to altered flow regimes: a literature review to inform the science and management of environmental flows, Freshwater Biol., 55, 194 205, 2010.

Poff, N. L., Allan, J. D., Bain, M. B., Karr, J. R., Prestegaard, K. L., Richter, B. D., Sparks, R. E., and Stromberg, J. C.: The natural flow regime, Bioscience 47, 769-784, 1997.

Poff, N. L., Olden, J. D., Merritt, D., M., and Pepin, D. M.: Homogenization of regional river dynamics by dams and global biodiversity implications, P. Natl. Acad. Sci. USA, 104, 5732-5737, 2007.

Poff, N. L., Richter, B. D., Arthington, A. H., Bunn, S. E., Naiman, R. J., Kendy, E., Acreman, M. C., Apse, C., Bledsoe, B. P., Freeman, M. C., Henriksen, J., Jacobson, R. B., Kennen, J. G., Merritt, D. M., O'Keeffe, J. H., Olden, J. D., Rogers, K., Tharme, R. E., and Warner, A.: The ecological limits of hydrologic alteration (ELOHA): a new framework for developing regional environmental flow standards, Freshwater Biology, 55, 147-170, https://doi.org/10.1111/j.1365-2427.2009.02204.x, 2009.

Postel, S. L. and Richter, B. D.: Rivers For Life: Managing Water for People and Nature, Island Press, 2003.

Riahi, K., Rao, S., Krey, V., Cho, C., Chirkov, V., Fischer, G., Kindermann, G., Nakicenovic, N., and Rafaj, P.: RCP8.5 - A scenario of comparatively high greenhouse gas emissions, Climatic Change, 109, 33-57, https://doi.org/10.1007/s10584-011-0149y, 2011.

Richter, B. D.: Re-thinking environmental flows: from allocations and reserves to sustainability boundaries, River Res. Appl., 26, 1052-1063, https://doi.org/10.1002/rra.1320, 2009.

Richter, B. D. and Thomas, G. A.: Restoring environmental flows by modifying dam operations, Ecol. Soc., 12, 12, 2007.

Richter, B. D., Davis, M. M., Apse, C., and Konrad, C.: A presumptive standard for environmental flow protection, River Res. Appl., 28, 1312-1321, https://doi.org/10.1002/rra.1511, 2012.

Rosenberg, D. M., McCully, P., and Pringle, C. M.: Global-Scale Environmental Effects of Hydrological Alterations: Introduction, BioScience, 50, 746-751, 2000.

RSIS: Ramsar Sites Information Service, available at: https://rsis. ramsar.org/, last access: 27 January 2015.

Savarenskiy, A. D.: Metod rascheta regulirovaniya stoka (A method for streamflow control computation), Gidrotekh. Stroit., 2, 24 28, 1940 .

Schmeier, S.: International RBO Database, Transboundary Freshwater Dispute Database (TFDD), Oregon State University, Corvallis, OR, available at: http://www.transboundarywaters.orst edu/research/RBO/RBO_Database.html, last access: 27 July 2014.

Schneider, C.: River ecosystems at risk, Modelling and assessing the impacts of dam operation, water use and climate change on global and continental river flow regimes, dissertation, KOBRA Dokumentenserver, University of Kassel, Germany, 1-163, available at: http://nbn-resolving.de/urn:nbn:de: hebis:34-2015121849487 (last access: 6 June 2017), 2015.

Schneider, C., Flörke, M., Eisner, S., and Voss, F.: Large scale modelling of bankfull flow: an example for Europe, J. Hydrol., 408, 235-245, 2011a. 
Schneider, C., Flörke, M., Geerling, G., Duel, H., Grygoruk, M., and Okruszko, T.: The future of European floodplain wetlands under a changing climate, J. Water Clim., 2, 106-122, 2011b.

Schneider, C., Laizé, C. L. R., Acreman, M. C., and Flörke, M.: How will climate change modify river flow regimes in Europe?, Hydrol. Earth Syst. Sci., 17, 325-339, https://doi.org/10.5194/hess-17-325-2013, 2013.

Siebert, S., Henrich, V., Frenken, K., and Burke, J.: Global Map of Irrigation Areas version 5, Rheinische Friedrich-WilhelmsUniversity, Bonn, Germany/Food and Agriculture Organization of the United Nations, Rome, Italy, 2013.

Smakhtin, V., Revenga, C., and Döll, P.: Taking into Account Environmental Water Requirements in Global-scale Water Resources Assessments, Comprehensive Assessment of Water Management in Agriculture Research Report 2 (IWMI, Colombo), 2004.

Smakhtin, V. U. and Eriyagama, N.: Developing a software package for global desktop assessment of environmental flows, Environ. Modell. Softw., 23, 1396-1406, 2008.

Sparks, R. E.: Need for Ecosystem Management of Large Rivers and Their Floodplains, Bioscience, 45, 168-182, 1995.

Swiss Re: World insurance in 2013: steering towards recovery, http: //media.swissre.com/documents/sigma3_2014_en.pdf (last access: 17 May 2015), 2014.

Taylor P. J., Walker G. R., Hodgson G., Hatton T. J., and Correll, R. L.: Testing of a GIS Model of Eucalyptus largiflorens health on a semiarid, saline floodplain, Environ. Manage., 20, 553-564, 1996.

Tharme, R. E. and King, J. M.: Development of the Building Block Methodology for instream flow assessments, and supporting research on the effects of different magnitude flows on riverine ecosystems, Water Research Commission Report No. 576/1/98, 452 pp., 1998.

Tockner, K. and Stanford, J. A.: Riverine flood plains: present state and future trends, Environ. Conserv., 29, 308-30, 2002.

Tockner, K., Malard, F., and Ward, J. V.: An extention of the flood pulse concept, Hydrol. Process., 14, 2861-2883, 2000.

UDI (Utility Data Institute): World Electric Power Plants Database, Platts Energy InfoStore, available at: http://www.platts.com (last access: 17 April 2012), 2004

Uluocha, N. O. and Okeke, I. C.: Implications of wetlands degradation for water resources management: Lessons from Nigeria, GeoJournal, 61, 151-154, 2004.

UNEP: Vital Water Graphics - An Overview of the State of the World's Fresh and Marine Waters, 2 nd Edn., UNEP, Nairobi, Kenya. ISBN: 92-807-2236-0, available at: http://www.grida.no/ publications/vg/water2/page/3262.aspx (last access: 1 February 2017), 2008.

USGS: Global Land Cover Characterization (GLCC), available at: http://edc2.usgs.gov/glcc/glcc.php (last access: 27 June 2012), 2008.

van Beek, L. P. H., Wada, Y., and Bierkens, M. F. P.: Global monthly water stress: 1. Water balance and water availability, Water. Resour. Res., 47, W07517, https://doi.org/10.1029/2010wr009791, 2011.
Verzano, K. and Menzel, L.: Snow conditions in mountains and climate change - a global view, in: Hydrology in Mountain Regions: Observations, Processes and Dynamics, Proceedings of Symposium HS1003 at IUGG2007, Perugia, July 2007, 147154, 2009.

Verzano, K., Bärlund, I., Flörke, M., Lehner, B., Kynast, E., and Voß, F.: Modeling variable river flow velocity on continental scale: Current situation and climate change impacts in Europe, J. Hydrol., 424-425, 238-251, 2012.

Vörösmarty, C. J., Sharma, K. P., Fekete, B. M., Copeland, A. H., Holden, J., Marble, J., and Lough, J. A.: The storage and aging of continental runoff in large reservoir systems of the world, Ambio, 26, 210-219, 1997.

Vörösmarty, C. J., McIntyre, P. B., Gessner, M. O., Dudgeon, D., Prusevich, A., Green, P., Glidden, S., Bunn, S. E., Sullivan, C. A., Reidy Liermann, C., and Davies, P. M.: Global threats to human water security and river biodiversity, Nature 467, 555-561, https://doi.org/10.1038/nature09440, 2010.

Watts, R. J., Richter, B. D., Opperman, J. J., and Bowmer, K. H.: Dam reoperation in an era of climate change, Mar. Freshwater Res., 62, 321-327, 2011.

WCD (World Commission on Dams): Dams and development: a new framework for decision-making, Earthscan, London, UK, 2000 .

Weedon, G. P., Balsamo, G., Bellouin, N., Gomes, S., Best, M. J., and Viterbo, P.: The WFDEI meteorological forcing data set: WATCH Forcing Data methodology applied to ERAInterim reanalysis data, Water Resour. Res., 50, 7505-7514, https://doi.org/10.1002/2014WR015638, 2014.

Welcomme, R.: Fisheries ecology of floodplain rivers, London: Longman, 1979.

Wilding, T. K. and Poff, N. L.: Flow-ecology relationships for the watershed flow evaluation tool, in: Watershed Flow Evaluation Tool Pilot Study for Roaring Fork and Fountain Creek Watersheds and Site-specific Quantification Pilot Study for Roaring Fork Watershed, edited by: Bledsoe, B. D., Miller, W. J., Poff, N. L., Sanderson, J. S., and Wilding, T. K., Colorado Water Conservation Board: Denver, Colorado, 2008.

WWF (World Wildlife Fund): Rivers at risk: dams and the future of freshwater ecosystems, available online at: http://assets. panda.org/downloads/riversatriskfullreport.pdf (last access: 11 May 2015), 2004.

WWF (World Wildlife Fund): Living Planet Report 2014: species and spaces, people and places, edited by: McLellan, R., Iyengar L., Jeffries, B., and Oerlemans, N., WWF, Gland, Switzerland, 2014.

Zarfl, C., Lumsdon, A. E., Berlekamp, J., Tydecks, L., and Tockner, K.: A global boom in hydropower dam construction, Aquat. Sci., 77, 161-170, https://doi.org/10.1007/s00027-014-0377-0, 2014. 